TELAGA BAHASA

Volume 5

No. 2 Desember 2017

Halaman 179-192

\title{
INTERPRETASI HERMENEUTIK PUISI PEMBIDAS KARYA AJAMUDDIN TIFANI
}

\section{(Hermeneutic Interpretation in Ajamudin Tifani "Pembidas")}

\author{
Agus Yulianto \\ Balai Bahasa Provinsi Kalimantan Selatan \\ Jalan A. Yani, Km 32,2 Loktabat, \\ Banjarbaru, Kalimantan Selatan, Telp: 0511-4772641 \\ Pos-el: agusb.indo@gmail.com
}

\begin{abstract}
Abstrak
Tulisan Puisi Pembidas karya Ajamuddin Tifani merupakan sebuah puisi yang banyak mengandung makna positif. Tujuan penelitian ini adalah mengetahui makna utuh puisi Pembidas karya Ajamudddin Tifani dengan menggunakan pendekatan hermeneutik. Adapun masalah dalam penelitian ini adalah makna apa sajakah yang terkandung dalam Puisi "Pembidas" karya Ajamuddin Tifani. Kajian ini menggunakan metode deskriptif kualitatif dengan teknik analisis data puisi per baris kemudian dilanjutkan secara keseluruhan. Berdasarkan hasil analisis dapat diketahui bahwa makna puisi Pembidasini antara lain membicarakan keingkaran manusia terhadap Tuhannya. Keingkaran itu sesungguhnya sudah terjadi sejak lama, yaitu sejak zaman kaum Madyan, Rass, Tsamud, dan Sodom. Mereka adalah orang-orang yang menjadikan berhala dan hawa nafsu sebagai tuhannya. Akan tetapi, dalam zaman modern seperti ini, keingkaran mereka mengalami sedikit transformasi. Mereka tetap menyembah berhala, tetapi bukan yang berbentuk patung melainkan yang berwujud uang, harta, dan teknologi.
\end{abstract}

Kata kunci: Puisi, hermeneutik, Ajamuddin Tifani

\section{Abstract}

This "Pembidas "of Ajamuddin Tifani is a poetry that has lots of positive meanings. The purpose of this study was to understand the integral meaning of poetry Pembidas by Ajamudddin Tifani by using a hermeneutic approach. The problem of this study describes the meaning of Pembidas by using hermeneutic approach. This study used descriptive qualitative method with data analysis technique in each line of poetry and then proceeded as a 
whole. Based on the result of the analysis, it can be seen that the meaning of Pembidas is about the disobedient of human against his/ her God. This has actually taken place for a long time since the days of the Madyan, Rass, Thamud, and Sodom. They are the people who make idols and passions as their Lord. However, in modern times like this, their disobedient is slightly transformed. They continue to worship idols, but not as sculptures but in the form of money, possessions, and technology.

Keywords: Poetry, hermeneutic, Ajamuddin Tifani

\section{PENDAHULUAN}

Kalimantan Selatan memiliki banyak penyair yang boleh dikatakan cukup produktif. Salah satunya adalah Ajamuddin Tifani. Oleh sebab itu, tidak heran bila Abdul Hadi WM dalam buku Tanah Perjanjian (2005) mengatakan: "Melalui antologi posmorfemnya ini tak diragukan lagi dia merupakan seorang dari penulis sajak generasi 1980-an yang produktif dan mampu mempertahankan kreativitasnya secara ajeg hingga akhir hayatnya...”.

Pokja Riset dan Dokumentasi Sastra (PDS) Kalimantan Selatan menggolongkan Tifani sebagai sosok seniman serba bisa dan fenomenal di zamannya. Di samping menulis puisi, cerpen, esai sastra dan budaya, Ajamuddin juga seorang pembaca puisi andal, penulis naskah drama, aktor sekaligus sutradara, pelukis, dan termasuk dewan redaksi seni dan budaya di Media Masyarakat dan Gaung.
Puisi-puisi yang dihasilkan oleh Tifani berjumlah ratusan. Setelah beliau meninggal, para sastrawan di Kalimantan Selatan bersepakat untuk mengumpulkan puisi-puisi beliau untuk didokumentasikan dalam bentuk antologi yang akhirnya terwujud dan diberi judul Tanah Perjanjian ini.

Salah satu puisi Tifani yang mendapat perhatian khusus dari sastrawan nasional, Abdul Hadi WM, adalah puisi yang berjudul Pembidas. Puisi tersebut sangat sarat dengan hikmah dan pencerahan bagi kehidupan spiritual manusia. Akan tetapi, seperti yang diketahui puisi adalah sebuah narasi wacana yang dipadatkan. Sebuah pengkristalan konsep dan ide melalui kata-kata yang terbatas. Bahkan menurut Adri (2016:494) puisi sebagai bagian dari sastra memiliki sistem tanda yang membedakannya dengan genre sastra lain. Artinya, ada syarat-syarat yang dimiliki oleh sebuah puisi sehingga disebut puisi. Dengan kata lain, sebuah karya disebut puisi jika ia berada dalam suatu 
wilayah yang menandakannya sebagai sebuah puisi. Tanda-tanda tersebut antara lain pembaitan, pilihan kata, rima, dan kata kias. Oleh Sebab itu, penjabaran pemaknaan terhadap sebuah puisi menjadi menarik untuk dilakukan.

Salah satu pendekatan yang dapat dilakukan untuk mendapatkan pemaknaan yang mendalam terhadap sebuah puisi adalah melalui pendekatan hermeneutik. Hermeneutik merupakan sebuah seni penafsiran puisi yang melihat puisi itu secara utuh serta mengaitkannya dengan kode di luar bahasa, semisal kode budaya. Dengan menggunakan pendekatan hermeneutik diharapkan makna yang tersirat dan bukan hanya makna yang tersurat dapat terungkap dari kandungan sebuah puisi yang dianalisis.

Dengan demikian tujuan penelitian ini adalah untuk mengetahui makna utuh puisi Pembidas karya Ajamudddin Tifani dengan menggunakan pendekatan hermeneutik. Adapun masalah dalam penelitian ini adalah bagaimanakah analisis puisi Pembidas karya Ajamuddin Tifani dengan menggunakan pendekatan hermeneutik.

\section{TEORI}

Menurut Herman J. Waluyo (2010: 1), puisi adalah karya sastra dengan bahasa yang dipadatkan, dipersingkat, dan diberi irama dengan bunyi yang padu dan pemilihan kata-kata kias (imajinatif). Kata-kata dalam puisi benar-benar padat dan terpilih sehingga sangat indah bila dibaca. Slamet Muljana (dalam Rakhmat Djoko Pradopo, 2002:113) mendefinisikan puisi sebagai bentuk sastra dalam pengulangan suara atau kata yang menghasilkan rima, ritma, dan musikalitas. Puisi mengekspresikan pemikiran yang membangkitkan perasaan, yang merangsang imajinasi panca indera dalam susunan yang berirama. Semua itu merupakan sesuatu yang penting, yang direkam dan dekspresikan, dinyatakan dengan menarik dan memberi kesan.

Lalu, berkenaan dengan kermeneutika, menurut Palmer (2005:15), hermeunetika merupakan studi pemahaman terhadap sebuah teks. Secara etimologis, hermeneutika berasal dari istilah Yunani, yakni hermeneuein (kata kerja) yang berarti menafsirkan, dan hermeneia (kata benda) yang berarti interpretasi. Kata hermeios, hermeneuein (kata kerja) dan hermeneia (kata benda) diasosiasikan pada Dewa Hermes. Bentuk kata yang beragam itu mengasumsikan adanya proses menggiring sesuatu atau situasi dari yang sebelumnya tak dapat dipahami menjadi dapat dipahami. Lebih lanjut, Palmer (2005:16) juga menyatakan terdapat tiga bentuk makna dasar dari hermeneuein dan hermeneia untuk 
memahami sebuah teks, yaitu: 1) pernyataan tidak mengalami alienasi dan mengungkapkan kata-kata; 2) menjelaskan seperti menjelaskan sebuah situasi; dan 3) menyesatkan pembacanya. menerjemahkan, seperti di dalam leterasi bahasa asing. Ketiga makna itu membentuk sebuah makna independen dan signifikan bagi interpretasi.

Menurut Hasan (2015:111), dalam ruang lingkup kesastraan, penggunaan metode hermeneutika sangat dibutuhkan. Tanpa interpretasi dan penafsiran pembaca terhadap sebuah karya sastra, karya tersebut hanyalah sebuah karya yang tidak memiliki nilai. Penelitian sastra harus mencari sebuah "metode" atau "teori" yang secara khusus tepat sebagai uraian kesan manusia terhadap makna dalam sebuah karya. Proses uraian, pemahaman makna sebuahkarya merupakan fokus hermeneutika. Tugas interpretasi harus membuat sesuatu yang kabur, jauh, dan gelap maknanya menjadi sesuatu yang jelas, dekat, dan dapat dipahami. Hermeneutika membantu pemaknaan sebuah kata tunggal untuk mengartikan keseluruhan kalimat yang ada.

Menurut Faiz (2002:103), salah satu tugas hermeneutik adalah menghidupkan dan merekonstruksi sebuah teks dalam jaringan interaksi antara pembicara, pendengar, dan kondisi batin serta sosial yang melingkupinya agar sebuah

Sangidu, 2004:14) memaparkan bahwa pembacaan hermeneutik atau retroaktif merupakan kelanjutan dari pembacaan heuristik untuk mencari makna (meaning of meaning atau significance). Hermeneutik merupakan pembacaan bolak-balik melalui teks dari awal hingga akhir. Tahap pembacaan ini merupakan interpretasi tahap kedua yang bersifat retroaktif yang melibatkan banyak kode di luar bahasa dan menggabungkannya secara integratif sampai pembaca dapat membongkar secara struktural guna mengungkap makna makana (significance) dalam sistem tertinggi, yakni makna keseluruhan teks sebagai sistem tanda.

Scheirmacher (dalam Palmer, 2005:97) berpendapat bahwa hermeneutika merupakan seni pemahaman. Pemahaman bagi sebuah seni mengalami proses mental dari pengarang teks. Pengarang membentuk kalimat, sedangkan pendengar membuat struktur kalimat dan pikirannya. Dengan demikian, interpretasi terdiri dari dua interaksi, yaitu gramatis dan psikologis. Adanya kolaborasi antara interaksi gramatis dan psikologis menyebabkan adanya lingkaran Hermeneutika. 
Lebih lanjut, Scheirmacher (dalam Hasan, 2015:111) menyatakan lingkaran hermeneutika ada ketika pemahaman sebuah karya sastra secara umum terdiri dari bagianbagian yang khusus. Lingkaran secara keseluruhan mendefinisikan bagian-bagian individu dan bagian-bagian tersebut bersamasama membentuk lingkaran. Konsep lingkaran hermeneutis melibatkan kontradiksi logis karena pemahaman bagianbagian dalam sebuah makna sangat diperlukan untuk memahami makna secara keseluruhan. Secara logika sebuah bagian telah menderivikasikan sebuah makna dari keseluruhan. Terkadang kalimat tunggal akan menjelaskan dan menggambarkan semua yang terjadi sebelumnya tanpa koherensi pada keseluruhan maknanya. Selain itu, lingkaran hermeneutis memerlukan kesamaan pengetahuan antara pembicara dengan pendengar atau antara penulis dengan pembaca. Tanpa adanya latar belakang pengetahuan terhadap sebuah persoalan yang dibahas, seseorang tidak akan dapat melangkah pada lingkaran hermeneutis.

\section{METODE}

Penelitian ini merupakan penelitian kualitatif dengan menggunakan metode deskriptif. Menurut Endaswara (2013:176), deskriptif kualitatif mengutamakan penggambaran data melalui kata-kata. Kata- kata memuat ribuan makna dan setiap kata mendukung jutaan makna.

Teknik analisis data dilakukan dengan menginterpretasikan data yang ada. Data diinterpretasikan maknanya perbagian dan selanjutnya secara keseluruhan dengan menggunakan interpretasi hermeneutik. Selanjutnya hasil analisis deskripsikan secara keseluruhan.

\section{PEMBAHASAN}

Interpretasi hermeneutik terhadap puisi Ajamuddin ini diawali dengan pemaparan teks puisi terlebih dahulu.

\section{Pembidas}

Bias dari Quran

Surah At Taubah

di Madyan, Tsamud, Rass, Sodom

(mereka kehilangan keesaan

Namun mereka mencarinya lagi

Sekarang bahkan itulah yang membawa mereka

Kepada berhala-berhala baru)

kami begitu majemuk di hadapan satumu saudara kandung kami sekarang adalah benda-benda

ibu bapak kami sekarang adalah uang dan mimpi teknologi

kami berguru kepada singa, mengimani nafsu-nafsu kami 
maaf, kedudukanmu kami geser ke tepi

sebab harta lebih menarik, nyata, dan asasi

kemajuan kami ukur dari materi ke teknologi

benda dan harta adalah takaran manusia kami

(perang memperanakkan perang,

kelaparan memberangus benua

gunung api dan banjir membarahkan derita

mengusir kemanusiaan ke rimbarimba tak bernama)

kami nikahi kemunafikan, kemungkaran, kebatilan

itulah sebabnya mengapa kami begitu serakah

agama kami lihat dari bursa, modal besar, dan komiditi

sekaligus menafsirkan firmanmu dalam bahasa komputer

mesin dan angka-angka

(ia tegakkan shalat di tengah pasar, dan orang-orang menertawakannya, ia tadahkan tangan ke langit, orang-orang melemparinya dengan batu dan tinja sekejap, langit pun merah, menyalakan bara bumi menjelma bumi, dan keangkaraan tetap seperti sediakala)

\section{Analisis Puisi Pembidas Karya Ajamuddin} Tifani dengan Interpretasi Hermeneutik

Puisi Pembidas memiliki enam bait. Bait pertama terdiri atas dua larik. Bait kedua terdiri atas sembilan larik. Bait ketiga terdiri atas empat larik. Bait keempat terdiri atas empat larik dan bait ini merupakan bait keterangan karena menggunakan kurung buka dan kurung tutup. Bait kelima terdiri atas empat larik. Bait keenam terdiri atas empat larik dan bait ini juga merupakan bait keterangan karena menggunakan kurung buka dan kurung tutup.

Kata Pembidas yang menjadi judul dari puisi ini merupakan kata yang masih asing terlihat dan terdengar di tengah masyarakat. Termasuk di Kalimantan Selatan. Kata Pembidas menurut Kamus Besar Bahasa Indonesia (KBBI, 2014:149) memiliki makna 1. (n) lembing yang dilepaskan dengan sesuatu yang melenting; 2. pasukan penggempur (penembus).

Kata Pembidas sediri berasal dari kata dasar bidas yang menurut Kamus Besar Bahasa Indonesia (KBBI, 2014:148) yang memiliki makna bergerak (terlepas, memantul) dengan cepat karena digerakkan oleh barang yang melenting atau karena 
dilepaskan tahanannya (seperti anak panah terlepas dari tali busurnya). Oleh sebab itu, judul puisi pembidas ini lebih mengarah kepada pemahaman terlepasnya ketauhidan dari diri manusia.

Pada larik ke-1 tampak penggunaan kata bias dan Quran. Kata bias mengandung arti simpangan dan belokan arah dari garis tempuhan karena menembus benda bening yang lain (seperti cahaya yang menembus kaca, bayangan yang ada di air). Kemudian terdapat kata Quran yang merupakan kitab suci agama Islam yang kebenarannya dianggap absolut atau mutlak. Larik pertama tersebut menggambarkan adanya pantulan atau bayangan Quran dalam puisi tersebut.

Pada larik ke-2 terdapat frase Surah At Taubah. Surat At-Taubah merupakan satu-satunya surat yang tidak diawali dengan bacaan basmalah, sementara surat Al Qur'an lainnya memakai bacaan basmalah. Adapun sebab tidak disebutkannya kalimat basmalah diawal surat At-Taubah, berdasarkan pendapat mayoritas Ulama, adalah karena surat ini berbicara tentang orang-orang kafir dan orang-orang munafik. Mereka diharamkan dari kalimat basmalah dan makna kasih sayang yang terdapat didalamnya. Oleh sebab itu, surat At Taubah lebih merepresentasikan kemurkaan Allah Swt kepada hamba-hamba yang ingkar kepada-Nya.
Pada larik ke-3 terdapat frase $d i$ Madyan, Tsamud, Rass, Sodom. Frase ini menyebutkan kaum-kaum yang mengingkari keberadaan Tuhan dan sangat ingkar kepadaNya. Mereka adalah para penyembah berhala dan juga hawa nafsu. Peristiwa-peristiwa berupa azab dari Allah Swt. kepada mereka diabadikan di dalam Quran.

Pada larik ke-4 terdapat klausa mereka kehilangan keesaan. Klausa ini merujuk kepada kaum Madyan, Tsamud, Rass, Sodom yang telah meninggalkan ajaran tauhid sebagai ajaran kebenaran tentang eksistensi Tuhan.

Pada larik ke-5 terdapat klausa namun mereka mencarinya lagi. Klausa ini merujuk pada “ideologi” kaum Madyan, Tsamud, Rass, Sodom yang tetap masih hidup dan terwariskan kepada orang-orang yang sejenis dengan mereka. Ideologi yang mengikuti jalan kesesatan, jalan yang jauh dari kebenaran.

Pada larik ke-6 terdapat klausa sekarang bahkan itulah yang membawa mereka. Klausa ini menjelaskan ideologi warisan " kaum Madyan, Tsamud, Rass, Sodom ini yang menjadi panduan hidup mereka dalam kehidupan di dunia ini.

Pada larik ke-7 terdapat klausa kepada berhala-berhala baru. Tuhan-tuhan yang mereka sembah bukan lagi seperti Tuhan-tuhan berwujud patung dan 
sebagainya yang menjadi berhala sesembahan. Akan tetapi, Tuhan-tuhan selain Allah Swt yang disembah oleh manusia sekarang berbeda dengan Tuhan-tuhan atau berhala-berhala zaman dulu.

Pada larik ke-8 terdapat klausa kami begitu majemuk di hadapan satumu. Klausa ini menjelaskan bahwa manusia itu terdiri dari berbagai ras dan bangsa yang berbedabeda. Begitu juga dengan warna kulit, bahasa, budaya, kedudukan, pangkat, kekayaan, pendidikan dan lain sebagainya. Akan tetapi, Tuhan menjadikan manusia berbeda-beda tersebut merupakan sebuah keniscayaan dikarenakan keesaan-Nya.

Pada larik ke-9 terdapat klausa saudara kandung kami sekarang adalah benda-benda. Klausa ini menjelaskan bahwa pertalian darah mereka bukanlah sesuatu yang hidup, tetapi sesuatu yang mati. Konsep persaudaraan, kesetiakawanan, saling memberi, saling menolong seakan sudah hilang entah kemana yang ada hanya mengagungkan benda-benda yang tak bernyawa yang hanya memberikan kesenangan sesaat.

Pada larik ke-10 terdapat klausa $i b u$ bapak kami sekarang adalah uang dan mimpi teknologi. Klausa ini menjelaskan bahwa panutan hidup manusia bukan lagi orang tua, melainkan harta. Teknologi sudah menjadi berhala dikarenakan ketakjuban manusia terhadap kepintaran dirinya sendiri. Manusia merasa besar dan mengecilkan Tuhannya. Padahal tidaklah manusia itu diberi ilmu melainkan hanya sedikit. Ilmu yang dimiliki manusia bila dibandingkan ilmu Allah Swt laksana setetes air di tengah samudra yang luas.

Pada larik ke-11 terdapat klausa kami berguru kepada singa, mengimani nafsunafsu kami. Klausa ini menjelaskan bahwa yang menjadi guru kehidupan bukan lagi kearifan, kebijaksanaan, ketenangan, tetapi yang menjadi guru kehidupan adalah kebuasan, pemangsa yang lemah, dan kekuatan semata. Selain itu, yang menjadi kepercayaan dari kehidupan ini bukan lagi kebenaran, yaitu Tuhan yang Esa, melainkan hawa nafsu. Hal ini juga terdapat dalam Quran yang menyatakan keprihatinan terhadap orang-orang yang menjadikan hawa nafsu menjadi Tuhannya.

Pada larik ke-12 terdapat klausa maaf, kedudukanmu kami geser ke tepi. Klausa ini menjelaskan tentang terpinggirkannya kebenaran, tujuan hidup yang lurus, dan hakikat penciptaan manusia dari kehidupan mereka. Bahkan segala nilainilai kehidupan yang mulia sudah bukan lagi menjadi tujuan hidup utama.

Pada larik ke-13 terdapat klausa sebab harta lebih menarik, nyata, dan asasi. Klausa ini menjelaskan bahwa orientasi 
hidup manusia sudah terjebak pada unsur kebendaan semata. Harta adalah sesuatu yang nyata, bisa diraba dan dirasakan secara inderawi. Manfaatnya pun bisa langsung dirasakan. Oleh sebab itu, banyak manusia yang terjebak dan berlomba-lomba saling memperbanyak harta. Akan, tetapi harta sebenarnya adalah harta yang dimanfaatkan untuk kepentingan agama.

Pada larik ke-14 terdapat klausa kemajuan kami ukur dari materi ke teknologi. Klausa ini menjelaskan bahwa paradigma berpikir sebagian orang saat ini yang dianggap sebagai kemajuan atau kemodernan adalah tersedianya materi atau harta yang berlimpah dan teknologi yang semakin maju. Bahkan tidak sedikit manusia yang mempertuhankan teknologi atau memberhalakan teknologi. Semakin maju teknologi maka seakan-akan semakin terpinggirkannya peran dan keberadaan Tuhan. Tuhan seakan-akan tidak mengerti fisika, kimia, biologi, nuklir, dan lain sebagainya. Padahal semua ilmu itu berasal dari Allah Swt. Allah lah yang mengajarkan manusia dengan perantaraan kalam.

Pada larik ke-15 terdapat klausa benda dan harta adalah takaran manusia kami. Klausa ini menjelaskan bahwa benda atau materi dijadikan alat pengukur kehidupan seseorang. Seseorang dianggap berhasil bila mempunyai harta berlimpah, seseorang dianggap mulia bila memiliki materi yang berlebih. Takaran hidup manusia mulia tidak lagi didasarkan ketakwaannya kepada Tuhan. Kemuliaan manusia tidak lagi diukur dari kemuliaan akhlaknya dan ketertundukannya kepada Tuhan.

Pada larik ke -16 terdapat klausa perang memperanakkan perang. Klausa ini menjelaskan tentang keangkaramurkaan manusia yang dimanifestasikan dalam wujud peperangan. Peperangan menimbulkan luka, dendam, dan korban jiwa. Peperangan merupakan peradaban manusia yang sudah sangat tua, setua usia manusia itu sendiri. Peperangan terjadi lebih banyak disebabkan oleh hawa nafsu seperti ingin memperluas wilayah, merampas harta, dan menjadikan manusia lain sebagai bawahannya. Oleh sebab itu, tidak heran bila suatu peperangan menimbulkan peperangan lain. Baik itu atas nama balas dendam, kemerdekaan dan lain sebagainya.

Pada larik ke -17 terdapat klausa kelaparan memberangus benua. Klausa ini menjelaskan bahwa kelaparan yang terjadi di Afrika merupakan wujud dari ketidakpedulian manusia terhadap manusia yang lain. Manusia secara garis besar seakanakan hanya mementingkan kelompoknya saja dan abai terhadap kelompok manusia yang lain. Apabila kemanusiaan dijunjung secara benar tidak mungkin akan terjadi kelaparan 
yang menimbulkan begitu banyak korban manusia. Kepedulian terhadap sesama merupakan mata rantai yang dapat menolong sesama manusia itu sendiri.

Pada larik ke -18 terdapat klausa gunung api dan banjir membarahkan derita. Klausa ini menjelaskan tentang banyaknya bencana alam yang sesungguhnya merupakan teguran bagi manusia dari Tuhannya. Bencana alam berupa gunung meletus dan banjir menimbulkan derita bagi manusia. Hal itu merupakan teguran agar manusia kembali kepada ajaran Tuhannya.

Pada larik ke -19 terdapat klausa mengusir kemanusiaan ke rimba-rimba tak bernama. Klausa ini menjelaskan tentang terpinggirkannya bahkan hilang rasa kemanusiaan dari diri para manusia itu sendiri. Hal itu disebabkan telah hilangnya rasa ketertuhanan dalam diri manusia. Manusia terkadang tidak merasa bahwa bencana yang diterimanya merupakan teguran dari Allah Swt. Mereka terkadang beranggapan bahwa bencana alam yang terjadi semata-mata karena fenomena alam belaka. Hal itulah yang membuat rasa kemanusiaan seakan-akan telah pergi entah kemana.

Pada larik ke-20 terdapat klausa kami nikahi kemunafikan, kemungkaran, kebatilan. Klausa ini menjelaskan tentang pengakuan bagaimana persekutuan manusia dengan kemunafikan, kemungkaran, dan kebatilan sudah sangat begitu erat. Hal itu menandakan bahwa sifat-sifat tersebut sudah menjadi bagian yang integral dalam diri manusia. Selain itu, sifat-sifat tersebut sengaja diterima atau dimunculkan berdasarkan keinginan manusia itu sendiri karena mengikuti hawa nafsunya.

Pada larik ke-21 terdapat klausa itulah sebabnya mengapa kami begitu serakah. Klausa ini menjelaskan efek dari perseketuan dengan kebatilan adalah timbulnya sifat keserakahan terhadap materi. Keserakahan yang timbul karena memperturutkan hawa nafsu.

Pada larik ke-22 terdapat klausa agama kami lihat dari bursa, modal besar, dan komoditi. Klausa ini menjelaskan sudut pandang dari pemahaman keagamaan buka lagi dari perspektif kebenaran, kebajikan, kebijaksanaan, melainkan dari aktivitas ekonomi semata berupa keuntungan materi semata. Halal haram sudah bukan menjadi tolak ukur lagi dalam mendapatkan keuntungan ekonomi.

Pada larik ke-23 terdapat klausa sekaligus menafsirkan firmanmu dalam bahasa komputer. Klausa ini menjelaskan bahwa penafsiran terhadap Quran tidak lagi didasarkan pada penafsiran yang semestinya, melainkan lebih didasarkan pada manfaat praktis belaka berdasarkan kemajuan zaman. 
Pada larik ke-24 terdapat klausa mesin dan angka-angka. Klausa ini menjelaskan bahwa yang menjadi tuntunan hidup manusia bukan lagi Quran, melainkan kemajuan teknologi dan keuntungan materi semata yang dapat dikalkulasi.

Pada larik ke-25 terdapat klausa ia tegakkan shalat di tengah pasar, dan orangorang. Klausa ini menjelaskan tentang seseorang yang mencoba mengembalikan kembali aktivitas ekonomi, aktivitas kehidupan berdasarkan ketaatan kepada Tuhan. Aktivitas yang berdasarkan pada aturan-aturan Tuhan dan sebagai bentuk penghambaan kepada-Nya. Akan tetapi, reaksi masyarakat sungguh diluar dugaan. Reaksi tersebut terdapat dalam larik berikutnya.

Pada larik ke-26 terdapat klausa menertawakannya, ia tadahkan tangan ke langit. Klausa ini menjelaskan reaksi masyarakat terhadap ajakan untuk kembali kepada Tuhan ditengah kesibukan manusia mengejar materi belaka ternyata hanya menjadi bahan tertawaan belaka. Pada saat berdoa untuk memohon pertolongan dari Tuhan reaksi masyarakat terlihat dalam larik berikutnya

Pada larik ke-27 terdapat klausa orang-orang melemparinya dengan batu dan tinja. Klausa ini menjelaskan reaksi masyarakat terhadap ajakan untuk kembali kepada Tuhan menjadi lebih ekstrem, yaitu mulai melakukan kekerasan dan penghinaan terhadap orang tersebut. Hal itu berwujud lemparan batu dan tinja.

Pada larik ke-28 terdapat klausa sekejap, langit pun merah, menyalakan bara. Klausa ini menjelaskan tentang kemurkaan Tuhan terhadap nasib yang menimpa orang yang sedang menyeru kepada kebenaran. Kemurkaan Tuhan itu diasosiasikan berupa langit pun merah, menyala bara.

Pada larik ke-29 terdapat klausa bumi menjelma bumi, dan keangkaraan. Klausa ini menjelaskan bahwa penyembahan materi tetap menyembah materi walaupun peringatan dan nasehat untuk menyembah Tuhan telah datang. Dengan demikian, keangkaraan menjadi bagian dari kehidupan mereka.

Pada larik ke-30 terdapat klausa tetap seperti sediakala. Penyembahan yang berlebihan terhadap materi tetap berlanjut meskipun penyeru kebenaran telaah menyampaikan kebenaran. Mereka tetap dalam aktivitas keduniawiannya semata.

\section{Makna Utuh Puisi Pembidas Karya Ajamuddin Tifani}

Secara keseluruhan atau secara utuh makna puisi Pembidas ini membahas tentang keingkaran manusia terhadap Tuhannya. Pembidas merupakan kata yang mengacu 
pada terlepasnya sesuatu secara cepat. Dalam hal ini, ajaran tauhid yang merupakan ajaran kebenaran bagi seluruh umat manusia.

Penyimpangan manusia terhadap ajaran Quran atau ajaran tauhid sudah berlangsung sejak lama. Bahkan sudah diabadikan dalam Quran seperti kisah kaum Madyan, Tsamud, Rass, dan Sodom. Kaum tersebut lebih mempertuhankan materi dan hawa nafsu mereka sendiri yang berwujud berhala-berhala. Bergantinya waktu bukan berarti kaum-kaum yang menyimpang seperti mereka telah hilang dari muka bumi. Mereka tetap ada sampai saat ini dan mengalami transformasi dalam penyimpangan mereka. Saat ini yang mereka sembah bukan patung atau pohon lagi, melainkan uang, bendabenda materi, dan teknologi. Dengan demikian mereka tetap terkategorikan sebagai orang-orang yang mempertuhankan berhala dan hawa nafsu.

Mereka lebih mempercayai sesuatu yang dapat diserap oleh panca indera dibandingkan Tuhan yang keberadaan tidak dapat terlihat. Oleh sebab itu, tidak heran bila parameter atau alat ukur kemajuan manusia didasarkan pada kemajuan teknologi dan kemuliaan manusia semata-mata didasarkan oleh banyaknya harta. Bukan lagi oleh ketakwaan dan kemuliaan akhlak manusia.

Imbas dari alat ukur yang salah tersebut melahirkan keangkaramurkaan manusia yang berwujud perang, kelaparan, dan bencana alam. Hal itu juga disebabkan oleh sikap manusia itu sendiri yang lebih mengikuti jalan kebatilan yang dengan sendirinya melahirkan sifat munafik, kemungkaran, dan kebatilan. Mereka memandang pedoman hidup mereka bukan lagi berdasarkan ajaran Tuhan yang termaktub di dalam Al Quran, melainkan semata-mata dari keuntungan materi yang mereka dapatkan dengan mengesampingkan halal dan haram. Dengan demikian mereka menafsirkan ajaran Quran hanya berdasarkan keinginan hawa nafsu mereka saja.

Dalam kondisi seperti itu, masih terdapat manusia yang mencoba untuk menjalankan kebenaran yang termanifestasikan dalam bentuk ibadah kepada Allah Swt. Akan tetapi, ternyata manusia-manusia ingkar itu malah menertawakannya. Bahkan ketika manusia ilahi tersebut mencoba untuk berdoa kepada Allah Swt untuk memohon kebaikan, manusia-manusia ingkar itu malah melemparinya dengan batu dan kotoran. Perilaku manusia-manusia ingkar tersebut sesungguhnya telah membuat Tuhan marah. Akan tetapi, disebabkan kemahakasihan dan kemahasayangan-Nya sajalah yang membuat azab itu menjadi tertahan. Ironisnya, manusia-manusia ingkar tersebut tetap melakukan aktivitas keangkaraannya 
meskipun sudah diberi nasihat dan Pembidas ini membicarakan tentang peringatan. Hal itu menandakan bahwa keingkaran manusia terhadap Tuhannya. mereka lebih memperturutkan hawa nafsu Keingkaran itu sesungguhnya sudah terjadi mereka dibandingkan mengikuti jalan Tuhan- sejak lama, yaitu sejak zaman kaum Madyan, Nya.

\section{PENUTUP}

Puisi Ajamuddin Tifani yang berjudul Rass, Tsamud, dan Sodom. Mereka adalah orang-orang yang menjadikan berhala dan hawa nafsu sebagai Tuhannya. Akan tetapi, Pembidas ini sesunguhnya sangat sarat dalam zaman modern seperti ini, keingkaran mereka mengalami sedikit transformasi. dengan pesan-pesan positif yang ingin disampaikan kepada pembacanya. Akan tetapi, karena puisi merupakan sebuah narasi wacana yang dipadatkan atau sebagai sebuah pengkristalan terhadap konsep dan ide melalui kata-kata yang terbatas, maka pemaknaan sebuah puisi menjadi sebuah keharusan.

Pendekatan hermeunetika merupakan studi pemahaman terhadap sebuah teks. Oleh sebab itu, pembedahan terhadap puisi Pembidas ini sangat tepat dengan menggunakan pendekatan hermeneutik untuk mendapatkan pemahaman yang lebih mendalam. Berdasarkan uraian dalam analisis dapat disimpulkan sebagai berikut.

Puisi Pembidas ini memiliki enam bait yang terdiri atas 30 larik. Analisis puisi Pembidas ini dengan menggunakan pendekatan hermeneutik pertama-tama perlarik. Setelah itu dianalis secara utuh. Secara garis besar apabila dianalisis dengan menggunakan pendekatan hermeneutik, puisi 


\section{DAFTAR PUSTAKA}

Adri. 2016. Heuristik dan Hermeneutik dalam Puisi Saat-saat Terakhir Rasulullah Karya Husni Djamaluddin. Jurnal Sawerigading 22 (2): 493-504. Makassar: Balai Bahasa Sulawesi Selatan.

Endraswara, Suwardi. 2013. Metodologi Kritik Sastra. Yogyakarta: Penerbit Ombak.

Faiz, Fakhruddin. 2002. Hermeneutika Qur'ani: Antara Teks, Konteks dan Kontekstualisasi. Yogyakarta: Penerbit Qalam.

Hasan, Nita Handayani. 2015. Lagu Maniahulu Makatita dalam Pendekatan Hermeneutika. Jurnal Totobuang 3 (1) 109-115. Maluku: Kantor Bahasa Provinsi Maluku.

Palmer, Richard E. 2005. Hermeneutika: Teori Baru Mengenal Interpretasi. Yogyakarta: Pustaka Pelajar.

Pradopo, Rakhmat Djoko. 2002. Pengkajian Puisi. Yogyakarta: Gadjah Mada University Press.

Sangidu. 2004. Penelitian Sastra: Pendekatan, Metode, Teori, Teknik, dan Kiat. Yogyakarta: Sastra Arab FIB UGM

Tifani, Ajamuddin. 2005. Tanah Perjanjian: Antologi Puisi. Jakarta: Hasta Mitra.
Waluyo, Herman J. 2010. Pengkajian dan Apresiasi Puisi. Salatiga: Widyasari. 